\title{
Analisis Loan To Deposit Ratio (LDR) Pada PT Bank Woori Saudara Indonesia 1906, Tbk. Periode 2013- 2017
}

\author{
Hasan Fahmi Kusnandar ${ }^{1}$ \\ Politeknik Triguna Tasikmalaya \\ hasan.fahmikusnandar@gmail.com \\ Sri Mulyati ${ }^{2}$ \\ Politeknik Triguna Tasikmalaya \\ mulyatiesri1015@gmail.com \\ Yusa Yaum ${ }^{3}$ \\ Politeknik Triguna Tasikmalaya
}

\begin{abstract}
Abstrak - Kegiatan menghimpun dana yang berasal dari simpanan masyarakat baik dalam bentuk simpanan giro, tabungan, dan deposito berjangka. Simpanan ini sering disebut sebagai Dana Pihak Ketiga (PDK) yang merupakan salah satu komponen penting yang dibutuhkan oleh bank. Dan salah satu penanda keuangan yang menentukan penilaian kesehatan kinerja suatu bank yaitu likuiditas. Dengan memahami tingkat likuiditas, maka akan dapat diketahui pula kemampuan perusahaan dalam menunaikan kewajiban jangka pendeknya dalam pemenuhan kredit nasabah. Tujuan dari penelitian ini adalah untuk menganalisis Loan To Deposit Ratio Pada PT Bank Woori Saudara Indonesia 1906, Tbk periode 2013-2017. Metode yang digunakan dalam analisis Ini yaitu metode deskriptif. Sedangkan teknik pengumpulan data yang digunakan yaitu studi dokumentasi dan studi Pustaka dengan jenis data sekunder untuk mengumpulkan dokumen penting yaitu Laporan Keuangan PT. Bank Woori Saudara 1906, Tbk periode 2013-2017. Hasil Penelitian menunjukkan bahwa perolehan rasio Loan to Deposit Ratio pada PT Bank Woori Saudara Indonesia 1906, Tbk. Periode 2013-2017 condong mengalami kenaikan.
\end{abstract}

Kata Kunci: Kredit, Dana Pihak Ketiga, Loan to Deposit Ratio

Abstract - Several society account savings can be clearing, savings, and deposit. Those are the third party fund as an important part required by bank. One variable that shows the bank normality is liquidity. By comprehending liquidity level, the bank can recognize company skill in fulfilling short term obligation to offer customers credit.sThis investigations was aimed to analyze Loan to Deposit Ratio at PT. Bank Woori Saudara Indonesia, 1906 Tbk. 2013-2017 Period. This research method used descriptive method. Data collecting technique are dokumentation and literature studies. Data type secondary for collecting document from financial report of PT. Bank Woori Saudara Indonesia 1906, Tbk 2013-2017 Period. The result showed that the Loan to Deposit Ratio at PT Bank Woori Saudara Indonesia 1906, Tbk. 2013-2017 Period tends to increase.

Keywords: Credit, Third Party Funds, Loan to Deposit Ratio 


\section{PENDAHULUAN}

\section{Latar Belakang Penelitian}

Kegiatan menghimpun dana tersebut sebagian besar berasal dari simpanan masyarakat baik dalam bentuk simpanan giro, tabungan, dan deposito berjangka. Simpanan ini sering disebut sebagai Dana Pihak Ketiga (PDK) yang merupakan salah satu komponen penting yang dibutuhkan oleh bank. Masyarakat sebagai pemilik dana dapat saja menarik dana yang dimilikinya kapan pun dan bank harus sanggup mengembalikan seluruh dana yang dipakainya jika ingin tetap dipercaya oleh nasabahnya. Menurut Susilo (2010:240) " bank harus menjaga kepercayaan yang diberikan masyarakat dalam mengelola dana mereka". Agar dapat memelihara kepercayaan nasabah dalam mengelola dana yang dipercayakan kepada bank maka bank harus mengendalikan kinerja lembaga dengan menjaga tingkat kesehatan bank tersebut. Menurut Budisantoso dan Triandaru (2005:51) Kesehatan sebuah bank merupakan "Kemampuan bank untuk melakukan kegiatan operasional perbankan secara normal dan mampu memenuhi kewajiban dengan baik dan dengan cara-cara yang sesuai peraturan perbankan yang berlaku"

Salah satu penanda keuangan yang menentukan penilaian kesehatan kinerja suatu bank yaitu likuiditas. Dengan memahami tingkat likuiditas, maka akan dapat diketahui pula kemampuan perusahaan dalam menunaikan kewajiban jangka pendeknya dalam pemenuhan kredit nasabah. Menurut Ikatan Bankir Indonesia (2016:48) "likuiditas bank menunjukkan kemampuan bank menyediakan uang kas untuk memenuhi kewajiban dengan biaya wajar"

PT Bank Woori Saudara Indonesia 1906, Tbk. Telah menjalankan salah satu fungsinya yaitu sebagai media intermediasi dan untuk mengetahui apakah sudah optimal atau belum pemenuhan kegiatan tersebut, dapat dilihat dari perbandingan antara jumlah dana yang dihimpun dengan yang disalurkannya. Melalui perhitungan LDR dapat diketahui kemampuan bank membayar kembali penarikan yang dilakukan nasabah deposan dengan mengandalkan kredit yang diberikan sebagai sumber likuiditasnya.

Berikut ini penulis sajikan perolehan Loan to Deposit Ratio (LDR) pada PT.Bank Woori Saudara Indonesia 1906, Tbk periode 2013-2017.

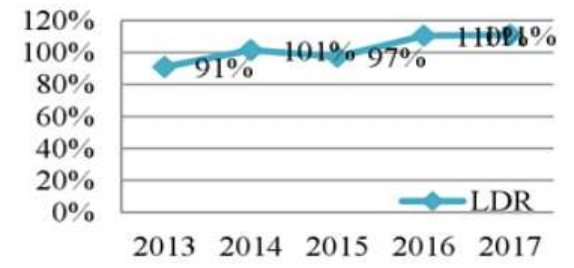

Gambar 1 Perolehan LDR PT. Bank Woori Saudara Indonesia 1906, Tbk periode 2013-2017

Berdasarkan gambar diatas persentase LDR pada PT Bank Woor Saudara Indonesia 1906, Tbk.

cenderung berada pada kisaran lebih dari ketentuan besaran persentase LDR bank yang ditetapkan oleh Bank Indonesia yaitu sebesar 78\%-92\% (Peraturan Bank Indonesia Nomor 15/15/PBI tahun 2013).

Dari latar belakang persoalan di atas, maka penulis terdorong untuk melakukan penelitian dengan judul : "Analisis Loan To Deposit Ratio (LDR) Pada PT Bank Woori Saudara Indonesia 1906, Tbk. periode 2013-2017".

\section{Rumusan Masalah}

Adapun rumusan masalah berlandaskan latar belakang diatas yaitu :

1. Bagaimana perkembangan simpanan nasabah pada PT Bank Woori 
Saudara Indonesia 1906, Tbk. periode 2013-2017?

2. Bagaimana perkembangan kredit nasabah pada PT Bank Woori Saudara Indonesia 1906, Tbk. periode 2013-2017?

3. Bagaimana pertumbuhan Loan to Deposit Ratio (LDR) pada PT Bank Woori Saudara Indonesia 1906, Tbk. periode 2013-2017.

\section{Tujuan Penelitian}

Adapun tujuan penelitian masalah berlandaskan latar belakang di atas yaitu

1. Untuk mengetahui perkembangan simpanan nasabah pada PT Bank Woori Saudara Indonesia 1906, Tbk. periode 2013-2017

2. Untuk mengetahui perkembangan kredit nasabah pada PT Bank Woori Saudara Indonesia 1906, Tbk. periode 2013-2017

3. Untuk mendapatkan hasil kajian mengetahui pertumbuhan Loan to Deposit Ratio (LDR) pada PT Bank Woori Saudara Indonesia 1906, Tbk. periode 2013-2017

\section{Kajian Pustaka}

Menurut kasmir (2017:51)

Manajemen Dana bank adalah "suatu kegiatan perencanaan, pelaksanaan dan pengendalian terhadap perhimpunan dana yang ada di masyarakat". Bagi bank, manajemen dana bank adalah bagaimana memilah dan mengelola sumber dana yang tersedia. Yaitu kegiatan mengelola sumber dana dari masyarakat luas, baik dalam bentuk simpanan giro, tabungan dan deposito. Dalam pengelolaan sumber dana dimulai dari penelitian akan kebutuhan dana, kemudian pelaksanaan pencarian sumber dana yang tersedia. Pengelolaan sumber dana kini dikenal dengan nama Manajemen Dana bank.
Menurut Frianto Pandia (2012:4) Manajemen Dana bank adalah "kegiatan yang meliputi bagaimana bank menetapkan kebijaksanaan dibidang usaha pengarahan dana (Source of funds) pengelolaan dan pengalokasian (Application funds) kedalam berbagai aktiva berdasarkan skala prioritasnya untuk mencapai tingkat laba yang optimal dengan tetap memelihara tingkat likuiditas yang sehat dengan batasanbatasan yang di tetapkan oleh bank sentral di Indonesia adalah Bank Indonesia".

Menurut Frianto Pandia (2012:4) ruang lingkup Manajemen Dana bank adalah :

1. Bagaimana bank mengelola harta/aktivanya (Asset management).

2. Bagaimana bank mengelola utangnya terhadap pihak ke tiga (liability management).

3. Bagaimana bank mengelola modalnya (Capital Management).

Menurut Kasmir (2017:50) Sumber Dana bank adalah "usaha bank dalam menghimpun dana dari masyarakat". Perolehan dana ini tergantung dari bank itu sendiri, apakah dari simpanan masyarakat atau dari lembaga lainnya. Kemudian untuk membiayai operasi nya, dana dapat pula diperoleh dari modal sendiri, yaitu dengan mencabut atau menjual saham. Perolehan dana disesuaikan pula dengan tujuan dari pemanfaatan dana tersebut. Penentuan sumber dana akan menentukan besar kecilnya biaya yang ditanggung. Kegiatan bank yang ke dua setelah menghimpun dana dari masyarakat luas dalam bentuk giro, tabungan dan deposito yaitu menyalurkan kembali dana tersebut kepada masyarakat. Kegiatan penyaluran dana ini dikenal dengan istilah alokasi dana.

Untuk menilai suatu kesehatan bank dapat ditinjau dari berbagai sudut. 
Penilaian ini bertujuan untuk memutuskan apakah bank tersebut dalam kondisi yang sehat, cukup sehat, kurang sehat dan tidak sehat sehingga bank Indonesia sebagai pengawas dan Pembina bankbank dapat memberikan bimbingan atau petunjuk bagaimana bank tersebut harus dijalankan atau bahkan dihentikan kegiatan operasinya.

Menurut Frianto Pandia (2012:2020) kesehatan suatu bank merupakan keperluan seluruh pihak terkait pemilik, pengelola bank, masyarakat pengguna jasa bank, maupun bank Indonesia sebagai Pembina dan pengawas bankbank sebagai tangan kanan dari pihak pemerintah.

Hasil dari penilaian kesehatan bank dapat digunakan oleh bank sebagai salah satu sarana dalam menetapkan strategi usaha diwaktu yang akan datang sedangkan bagi bank Indonesia antara lain digunakan sebagai sarana penetapan dan implementasi strategi pengawasan bank oleh bank Indonesia.

Menurut Kashmir (2017:300) penilaian untuk menentukan kondisi suatu bank yaitu menggunakan analisis CAMELS. CAMELS merupakan kepanjangan dari Capital, Asset, Management, Earning, Liquidity, Sensitivity.

Menurut Edward W.Reed dan Edward K.Gill dalam Frianto Pandia (2012:112) mengatakan "Likuiditas adalah kualitas aset yang membuatnya mudah dikonversi menjadi uang tunai dengan sedikit atau tidak ada risiko kehilangan". Menurut pengertian ini bank disebut likuid apabila bank tersebut memiliki kemampuan menyediakan uang tunai atau alat-alat pembayaran lainnya yang cukup, baik dari sumber-sumber lain dengan biaya rendah dan tidak mengakibatkan kerugian bagi bank.

Menurut Frianto Pandia (2012:114) manajemen likuiditas diartikan sebagai suatu kegiatan yang melingkupi perkiraan secara terus menerus akan kebutuhan kas yang seketika dihadapi oleh bank, perkiraan kebutuhan jangka pendek dan kebutuhan perkiraan kas jangka panjang. Menurut Kasmir (2017:315) Rasio Likuiditas adalah "Rasio untuk mengukur kemampuan bank dalam memenuhi kewajiban jangka pendeknya pada saat ditagih". Dengan kata lain, dapat membayar kembali pencairan dana deposannya pada saat ditagih serta dapat mencukupi permintaan kredit yang telah diajukan. Semakin besar rasio ini semakin likuid. Likuiditas dimaksudkan sebagai pertimbangan antara jumlah uang tunai dan aktiva lain yang dapat disamakan dengan uang disatu pihak dengan jumlah utang lancar dipihak lain. Menurut Sudirman (2013:107) "Metode dalam perhitungan likuiditas yaitu dengan analisis Loan to Deposit Ratio (LDR)".

Menurut Kasmir (2017:319) LDR atau disebut juga rasio kredit terhadap total dana pihak ketiga yang digunakan untuk mengukur dana pihak ketiga yang disalurkan dalam bentuk kredit. Bila bank dapat menyalurkan seluruh dana yang dihimpun maka hal tersebut akan menguntungkan, namun hal ini terkait dengan risiko apa bila sewaktu-waktu pemilik dana menarik dananya atau pemakai dana tidak dapat mengembalikan dana yang dipinjamnya. Sebaliknya, apabila bank tidak menyalurkan dananya maka bank juga akan tertimpa risiko karena hilangnya kesempatan untuk memperoleh keuntungan.

Rasio ini dapat dihitung dengan rumus sebagai berikut :

$$
L D R=\frac{\text { Kredit }}{\text { dana pihak ketiga }} \times 100 \%
$$

\section{Frianto Pandia (2012:128)}

Berdasarkan peraturan Bank Indonesia no.15/15/PBI tahun 2013 standar pengukuran rasio Loan to Deposit 
Ratio (LDR) dapat dilihat pada table berikut ini :

Tabel 1 Persentase tingkat LDR

\begin{tabular}{|l|l|}
\hline Keterangan & Rasio \\
\hline Batas bawah & $78 \%$ \\
\hline Batas atas & $92 \%$ \\
\hline
\end{tabular}

(sumber: peraturan Bank Indonesia no.15/15/PBI tahun 2013)

Menurut Frianto Pandia (2012:128) Loan to Deposit Ratio (LDR) adalah "seberapa jauh bak telah menggunakan uang para penyimpan (Depositor) untuk memberikan pinjaman kepada nasabahnya". Maka penilaian LDR adalah posisi likuiditas untuk mengukur kemampuan bank dalam memenuhi kewajiban jangka pendeknya pada saat ditagih. Semakin tinggi LDR menunjukkan semakin riskan kondisi likuidas bank, sebaliknya semakin rendah LDR menunjukkan kurangnya efektivitas bank dalam menyalurkan kredit berikut penulis sajikan paradigma kerangka pikiran :

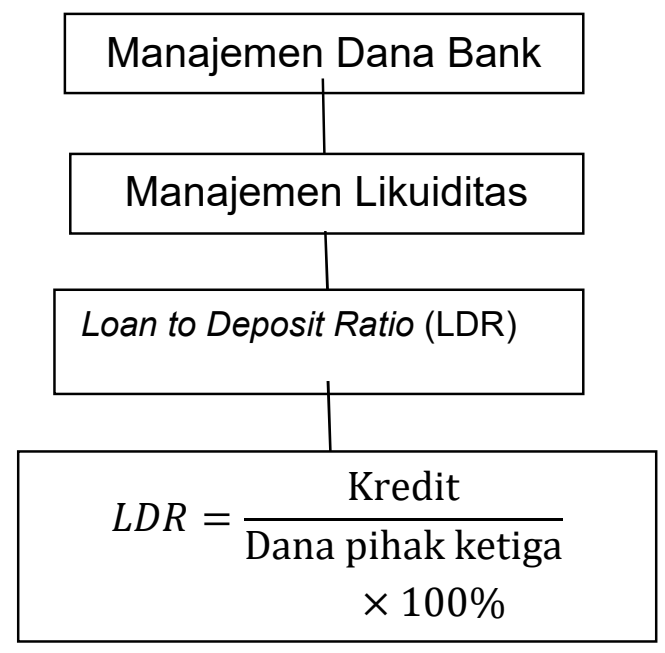

Gambar 2 Paradigma kerangka pemikiran

\section{METODE PENELITIAN}

Metode penelitian yang digunakan dalam penelitian ini adalah Metode Deskriptif. Menurut Moh.Nazir (2011:54) "metode deskriptif suatu metode dalam meneliti status sekelompok manusia, suatu objek, suatu set kondisi, suatu sistem pemikiran, ataupun suatu kelas peristiwa pada masa sekarang". Tujuan dari penelitian deskriptif ini adalah untuk membuat deskripsi, gambaran secara sistematis, faktual dan akurat mengenai fakta-fakta, sifat-sifat serta hubungan antar fenomena yang diselidiki.

\section{Operasional Variabel}

Menurut Sugiyono

(2013:59) variabel penelitian adalah "Suatu atribut atau sifat atau nilai dari orang, obyek atau kegiatan yang mempunyai variasi tertentu yang di tetapkan oleh peneliti untuk dipelajari dan ditarik kesimpulannya".

Untuk memudahkan pemahaman, variabel dalam penelitian ini penulis sajikan dalam tabel sebagai berikut :

\section{Jenis dan Sumber Data}

Jenis data yang dipakai dalam penelitian ini adalah data sekunder. Menurut Sugiyono (2013:193) "data sekunder merupakan sumber yang tidak langsung memberikan data kepada pengumpul data misalnya lewat dokumen".

Adapun sumber data yang dipakai penulis dalam penelitian ini diperoleh dari Laporan Keuangan PT Bank Woori Saudara Indonesia 1906, Tbk. Periode 2013-2017.

\section{Teknik pengumpulan data}

Untuk mengumpulkan data yang diperlukan dalam penelitian, penulis melakukan beberapa cara sebagai berikut:

1. Dokumentasi 


\begin{abstract}
Menurut Sugiyono (2013:422) dokumen merupakan "catatan peristiwa yang sudah berlalu". Dokumen bisa berbentuk tulisan, gambar, atau karya-karya monumental dari seseorang.

Dokumentasi dalam penelitian ini digunakan untuk mengumpulkan dokumentasi yang penting mengenai data Laporan Keuangan PT Bank Woori Saudara Indonesia 1906, Tbk. Periode 2013-2017 yang dipilih sebagai bahan penelitian. Adapun dokumen yang digunakan adalah laporan keuangan.
\end{abstract}

2. Studi Pustaka

$$
\text { Menurut Prastowo (2012:81) }
$$

"kegiatan studi pustaka bertujuan mengumpulkan data dan informasi ilmiah, berupa teori-teori, metode, atau pendekatan yang pernah berkembang dan telah didokumentasikan dalam bentuk buku, jurnal, naskah, catatan, rekaman sejarah, dokumendokumen, dan lain-lain yang terdapat di perpustakaan".

Dalam hal ini, penulis melakukan pengumpulan data dari buku-buku maupun sumber lainnya yang sesuai dengan penelitian yang dilakukan penulis.

\section{Teknik Analisis Data}

Adapun teknik penelitian data yang dilakukan oleh peneliti adalah sebagai berikut :

1. Mengumpulkan data laporan keuangan dari PT Bank Woori Saudara 1906, Tbk. periode 2013-2017.

2. Melakukan pengukuran-pengukuran atau perhitungan-perhitungan dengan memasukkan angka-angka yang ada dalam laporan keuangan ke dalam rumus rasio likuiditas LDR yaitu sebagai berikut :

$$
L D R=\frac{\text { Kredit }}{\text { Dana pihak ketiga }} \times 100 \%
$$

Frianto Pandia (2012:128)

3. Memberikan interpretasi terhadap hasil perhitungan dengan melihat kecondongan rasio dan dibandingkan dengan tingkat persentase LDR yang ditetapkan Bank Indonesia.

4. Membuat laporan hasil analisis berupa kesimpulan.

5. Memberikan rekomendasi berupa saran yang membangun.

\section{PEMBAHASAN}

\section{Hasil Penelitian}

Hasil penelitian ini adalah hasil dari pengukuran-pengukuran atau perhitungan dengan memasukkan angkaangka yang ada pada laporan keuangan ke dalam rumus Loan to Deposit Ratio (LDR). Pembahasan yang dilakukan dengan penginterpretasian dari analisis yang dilakukan dengan melihat kecenderungan rasio.

\section{Dana Pihak Ketiga}

Menurut Kasmir (2017:59) "sumber dana pihak ketiga merupakan simpanan dari masyarakat yang dapat berbentuk giro, tabungan dan deposito".

Berikut penulis sajikan persentase DPK atau dana simpanan rupiah pada PT Bank Woori Saudara Indonesia 1906, Tbk periode 2013-2017.

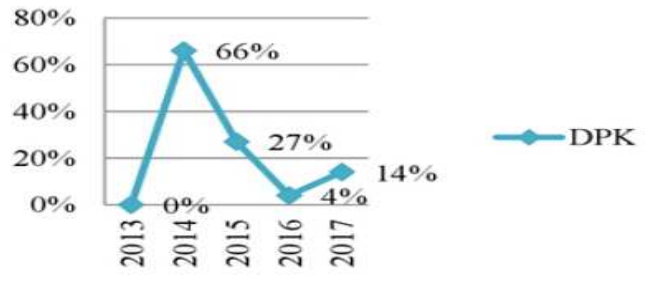

Gambar 3 Pertumbuhan DPK (Dana Pihak Ketiga) pada PT. Bank Woori Saudara Indonesia 1906, Tbk. Periode 2013-2017 
Berdasarkan Gambar 3 di atas dapat dilihat bahwa pertumbuhan DPK pada PT Bank Woori Saudara Indonesia 1906, Tbk paling tinggi terjadi pada tahun 2014 yaitu sebesar 66\%. Hal ini disebabkan karena pada tahun 2014 terjadi proses merger atau penggabungan usaha yang dilakukan oleh PT Bank Woori Saudara Indonesia 1906, Tbk. Sehingga jumlah DPK (dana pihak ketiga) mengalami peningkatan dengan dana yang cukup besar.

\section{Perkembangan Kredit}

Menurut Kasmir

$(2017: 84)$

Kegiatan Penyaluran Dana yang dilakukan oleh bank dikenal dengan istilah alokasi dana "yaitu menyalurkan kembali dana tersebut kepada masyarakat". Pengalokasian dana dapat diciptakan dalam bentuk pinjaman atau kredit. Dilihat dari segi kegunaannya kredit dibagi menjadi dua yaitu, kredit investasi dan kredit modal kerja serta dari segi tujuannya yaitu kredit konsumtif, kredit produktif, dan kredit perdagangan.

Tabel 4 Pertumbuhan Kredit Pada PT Bank Woori Saudara Indonesia 1906, Tbk Periode 2013-2017 (Dalam Jutaan Rupiah)

\begin{tabular}{|l|l|l|l|}
\hline Tahun & Kredit & $\begin{array}{l}\text { Perubahan } \\
\text { Kredit }\end{array}$ & $\begin{array}{l}\text { Pertum } \\
\text { buhan }\end{array}$ \\
\hline 2013 & 6.199 .381 & & \\
\hline 2014 & 11.468 .312 & 5.268 .931 & $85 \%$ \\
\hline 2015 & 13.958 .921 & 2.490 .609 & $22 \%$ \\
\hline 2016 & 16.440 .835 & 2.481 .914 & $18 \%$ \\
\hline 2017 & 18.804 .986 & 2.364 .151 & $14 \%$ \\
\hline
\end{tabular}

(Sumber: Laporan Keuangan PT Bank Woori Saudara Indonesia 1906, Tbk)
Untuk lebih jelasnya berikut penulis sajikan dalam bentuk grafik:

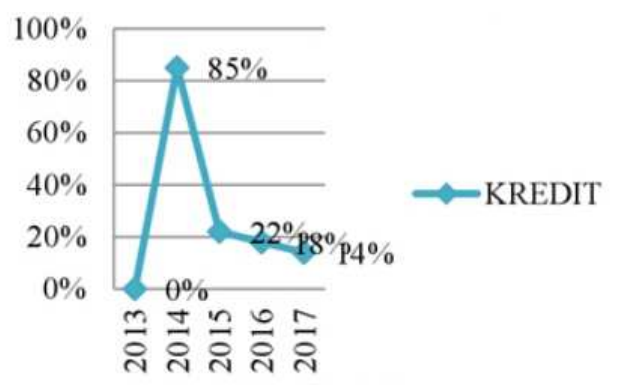

Gambar 4 Pertumbuhan Kredit pada PT Bank Woori Saudara Indonesia 1906, Tbk periode 2013-2017

Dari Gambar 4 di atas dapat diketahui bahwa pertumbuhan kredit pada PT Bank Woori Saudara Indonesia 1906, Tbk periode 2013-2017 tertinggi yaitu terjadi pada tahun 2014 sebesar $85 \%$. Hal ini dikarenakan pada tahun 2014 terjadi proses merger atau penggabungan usaha yang dilakukan oleh PT Bank Woori Saudara Indonesia 1906, Tbk sehingga perluasan penyaluran kredit diperbesar bersamaan dengan bertambahnya jumlah nasabah.

\section{Loan to Deposit Ratio (LDR)}

Menurut Frianto Pandia (2012:128) Loan to Deposit Ratio (LDR) adalah "seberapa jauh bank telah menggunakan uang para penyimpan (depositor) untuk memberikan pinjaman kepada nasabahnya". Maka penilaian LDR adalah posisi likuiditas untuk menilai kemampuan bank dalam memenuhi kewajiban jangka pendeknya pada saat ditagih.

Adapun rumus perhitungan LDR menurut Frianto Pandia (2012:128) adalah sebagai berikut:

$L D R=\frac{\text { Kredit }}{\text { Dana pihak ketiga }} \times 100 \%$

Berikut penulis sajikan perolehan LDR pada PT Bank Woori Saudara Indonesia 1906, Tbk. Periode 2013-2017 
Tabel 5 Perolehan Loan to Deposit Ratio (LDR) pada PT. Bank Woori Saudara Indonesia 1906, Tbk. Periode 2013-2017 (Dalam Jutaan Rupiah)

\begin{tabular}{|l|l|l|l|}
\hline Tahun & Kredit & DPK & LDR \\
\hline 2013 & 6.199 .381 & 6.802 .289 & $91,14 \%$ \\
\hline 2014 & 11.468 .312 & 11.303 .958 & $101,45 \%$ \\
\hline 2015 & 13.958 .921 & 14.346 .247 & $97,30 \%$ \\
\hline 2016 & 16.440 .835 & 14.879 .609 & $110,49 \%$ \\
\hline 2017 & 18.804 .986 & 16.928 .615 & $111,08 \%$ \\
\hline Rata-rata & & & $\mathbf{1 0 2 , 1 1 \%}$ \\
\hline Terendah & & & $\mathbf{9 1 , 1 4 \%}$ \\
\hline Tertinggi & & & $\mathbf{1 1 0 , 4 9 \%}$ \\
\hline
\end{tabular}

(Sumber: Laporan Keuangan PT Bank Woori Saudara Indonesia 1906, Tbk)

Untuk lebih jelasnya penulis sajikan dalam grafik berikut :

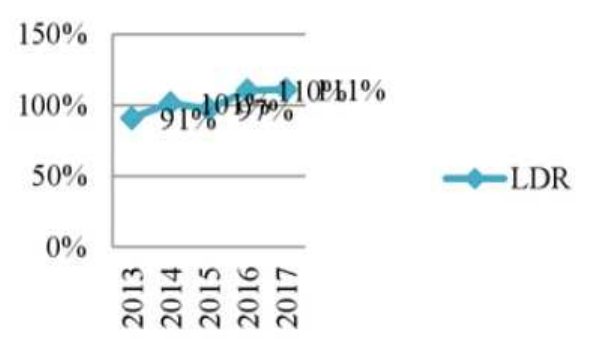

Gambar 5 Perolehan Loan to Deposit Ratio (LDR) PT. Bank Woori Saudara Indonesia, 1906 Tbk. Periode 2013-2017
Berdasarkan gambar 5 di atas dapat dilihat perolehan LDR pada lima tahun terakhir menunjukkan persentase angka yang lebih dari ketentuan batas perolehan LDR yang ditetapkan oleh Bank Indonesia yaitu sebesar 78\%-92\% (Peraturan Bank Indonesia Nomor 15/15/PBI tahun 2013).

Secara keseluruhan dapat diketahui bahwa perolehan persentase LDR pada PT Bank Woori Saudara Indonesia 1906, Tbk periode 2013-2017 mengalami kenaikan. Terhitung dari persentase LDR pada 2013 sebesar $91,14 \%$ sebelum adanya proses merger atau penggabungan usaha yang terjadi pada PT Bank Woori Saudara Indonesia 1906, Tbk. Persentase menunjukkan pada kisaran batas aman LDR yang telah ditetapkan Bank Indonesia. Kemudian pada 2014 persentasenya sebesar $101,45 \%$ sampai 2017 dengan persentase sebesar $111,08 \%$ LDR pada PT Bank Woori Saudara Indonesia 1906, Tbk. Mengalami kenaikan, meskipun pada 2015 terjadi penurunan yaitu menjadi $97,30 \%$ namun kisarannya masih berada lebih dari batas aman LDR yang telah ditetapkan oleh Bank Indonesia.

Hasil dari perhitungan Loan to Deposit Ratio (LDR) menunjukkan bahwa bank terlalu banyak menyalurkan kredit dibandingkan dengan memperoleh DPK. Berikut penulis sajikan perolehan dana yang didapat selain dari DPK :

Tabel 6 Perolehan Dana selain DPK (Dana Pihak Ketiga) pada PT Bank Woori Saudara Indonesia 1906, Tbk. Periode

\begin{tabular}{|l|c|c|c|c|c|}
\hline \multirow{2}{*}{ Keterangan } & \multicolumn{5}{|c|}{ Tahun } \\
\cline { 2 - 6 } & 2013 & 2014 & 2015 & 2016 & 2017 \\
\hline $\begin{array}{l}\text { Pinjaman } \\
\text { Yang } \\
\text { Diterima }\end{array}$ & 234.400 & 371.550 & 689.250 & 1.751 .425 & 2.035 .125 \\
\hline $\begin{array}{l}\text { Total } \\
\text { Liabilitas }\end{array}$ & 4.573 .918 & 12.528 .511 & 15.883 .592 & 18.218 .744 & 20.979 .506 \\
\hline $\begin{array}{l}\text { Total } \\
\text { Equitas }\end{array}$ & 1.647 .962 & 3.904 .265 & 4.135 .931 & 4.411 .890 & 6.106 .998 \\
\hline
\end{tabular}


Untuk memenuhi kekurangan karena jumlah kredit yang disalurkan lebih daripada perolehan Dana Pihak Ketiga (DPK), PT Bank Woori Saudara Indonesia 1906, Tbk. Menggunakan modal sendiri dan memperoleh dana berupa pinjaman yang diterima dari pihak lain.

Menurut Bank Indonesia, bank dianggap sehat apabila besarnya LDR antara $78 \%$ sampai dengan $92 \%$. Jika di atas $92 \%$ maka bank akan mengalami kesulitan likuiditas dan berdampak pada penurunan profitabilitas dan kinerja bank. Sanksi bagi bank di Indonesia yang tingkat LDR lebih rendah ataupun lebih tinggi dari ketentuan yang ditetapkan BI, maka $\mathrm{Bl}$ akan mengenakan denda sebesar $0,1 \%$ dari jumlah simpanan nasabah di bank bersangkutan untuk tiap $1 \%$ kekurangan LDR yang dialami Bank (PBI/15/15/2013). Sementara bank yang memiliki tingkat LDR diatas $100 \%$ akan diminta oleh BI untuk menambah setoran Giro Wajib Minimum (GWM) primer sebesar 0,2\% dari jumlah simpanan nasabah di bank bersangkutan untuk $1 \%$ nilai kelebihan LDR yang dialami bank, dimana penambahan dana GWM primer tidak diberikan bunga. Kecuali bagi bank yang memiliki CAR diatas $14 \%$ tidak terkena penalti.

\section{PENUTUP}

\section{Kesimpulan}

Berdasarkan hasil penelitian dan pembahasan yang telah dipaparkan, maka penulis dapat menyimpulkan :

1. Dana pihak ketiga pada PT Bank Woori Saudara Indonesia 1906, Tbk periode 2013-2017 cenderung mengalami penurunan.

2. Penyaluran kredit pada PT Bank Woori Saudara Indonesia 1906,
Tbk periode 2013-2017 cenderung mengalami kenaikan.

3. Pertumbuhan Loan to Deposit Ratio (LDR) pada PT Bank Woori Saudara Indonesia 1906, Tbk periode 2013-2017 cenderung mengalami kenaikan.

\section{Saran}

Berdasarkan hasil analisis perolehan Loan to Deposit Ratio (LDR) pada PT Bank Woori Saudara Indonesia 1906, Tbk periode 20132017 diketahui bahwa jumlah penyaluran kredit lebih besar dari dana pihak ketiga (DPK) yang masuk. Untuk itu yang harus dilakukan oleh bank adalah meningkatkan perolehan dana dari pihak ketiga. Menarik minat masyarakat untuk menabung dan menyimpan dananya ke bank dengan produk serta inovasi jenis tabungan lain atau pemberian reward yang menarik untuk nasabah.

\section{DAFTAR PUSTAKA}

Budisantoso, Totok dan Sigit Triandaru. 2006. Bank dan Lembaga Keuangan Lain. Jakarta: Salemba Empat.

Dendawijaya, Lukman. 2005. Manajemen Perbankan. Bogor : Ghalia Indonesia

Ikatan Bankir Indonesia. 2016. Manajemen Kesehatan Bank Berbasis Risiko. Jakarta: Gramedia Pustaka Utama.

Kasmir. 2017. Manajemen Perbankan. Jakarta: PT. Raja Grafindo Persada. 
Nazir, Moh. 2011. Metode Penilitian. Bogor: Ghalia Indonesia.

Pandia, Frianto. 2012. Manajemen Dana dan Kesehatan Bank. Cetakan Pertama. Jakarta: Rineka Cipta

Prastowo, Andi. 2012. Manajemen Perpustakaan Sekolah Profesional. Yogyakarta: Diva Press.

Sudirman, I wayan. 2013. Manajemen Perbankan Menuju Bankir Konvensional yang Profesional. Jakarta: Kencana.

Sugiyono. 2013. Metodologi Penelitian Kuantitatif, Kualitatif Dan R\&D. bandung: ALFABETA.

Susilo. 2010. Manajemen Perbankan. Jakarta: Salemba Empat

Taswan. 2010. Manajemen Perbankan Teori, Aplikasi. Cetakan Kedua Yogyakarta: UPP STIM YKPN

Umam, Khaerul. 2013. Manajemen Perbankan Syariah. Bandung: CV P. Setia.

\section{Sumber Dokumen :}

Laporan Keuangan PT Bank Woori Saudara 1906, Tbk, Annual Report 2013-2014, Annual Report 2015-2017. 